\title{
Effect of Deformation-Induced Martensite on Protective Performance of Passive Film on 304 Stainless Steel
}

\author{
Shanlin He, ${ }^{1, *}$ Daming Jiang ${ }^{1}$, Zhaoyuan Sun ${ }^{2}$ \\ ${ }^{1}$ School of Materials Science and Engineering, Harbin Institute of Technology, Harbin 150001, China \\ ${ }^{2}$ Center of Analysis and Measurement, Harbin Institute of Technology, Harbin 150001, China \\ *E-mail: 11B909025@hit.edu.cn
}

doi: $10.20964 / 2018.05 .11$

Received: 15 January 2018 / Accepted: 26 February 2018 / Published: 10 April 2018

\begin{abstract}
The relationships among the characteristics and electrochemical properties of passive films on the surfaces of 304 stainless steel specimens with different deformation-induced martensite content were examined using X-ray diffraction spectroscopy (XRD), transmission electron microscopy (TEM), Xray photoelectron spectroscopy (XPS) and electrochemical methods. The compound contents and protective performance of the passive film initially decreased and then increased with increasing deformation-induced martensite content. The passive film on the surface of a stainless steel specimen with an $\alpha^{\prime}$-martensite content of $6 \%$ was found to have the lowest contents of compounds and the poorest protective performance. When the $\alpha^{\prime}$-martensite content was less than $6 \%$, the compound contents and protective performance of the passive film on the surface of the stainless steel decreased with increasing $\alpha^{\prime}$-martensite content. When the $\alpha^{\prime}$-martensite content exceeded $6 \%$, the compound contents and protective performance of the passive film increased to a certain extent with increasing $\alpha^{\prime}-$ martensite content.
\end{abstract}

Keywords: martensite; passive film; 304 stainless steel; protective performance

\section{FULL TEXT}

(C) 2018 The Authors. Published by ESG (www.electrochemsci.org). This article is an open access article distributed under the terms and conditions of the Creative Commons Attribution license (http://creativecommons.org/licenses/by/4.0/). 